\title{
PERAN DAN KENDALA FINTECH SYARIAH PADA UMKM DI INDONESIA
}

\author{
Zahida I'tisoma Billah'1 \\ Nuntupa ${ }^{2}$ \\ Shariah Economics, Faculty of Islamic Economics and Business, Universitas \\ Islam Zainul Hasan Genggong, Probolinggo, Indonesia \\ Email: zahidafe@gmail.com ${ }^{1}$; nuntufa42@ gmail.com²
}

\begin{abstract}
Introduction : Fintech is a combination of financial management using technology. Fintech has become a public concern because this service provides various service features to make it easier from the financial side, such as those used in cooperative financial institutions, banking and insurance. This study aims to analyze the role of Fintech in increasing SMEs in Indonesia. Currently, Technological Developments are starting to enter the digital realm in order to welcome Indonesia as the largest digital economy country in 2024, the task of the government as Indonesia's economic regulator is to empower all Indonesian people to rural and remote areas in all corners of the country so that they can also feel the positive impact of the development. technology in the future. Methods: The research was conducted using descriptive qualitative methods. Sources of data in the form of secondary data with interview data collection techniques and documentation.

Results : The role of fintech can help SMEs actors in increasing their finances, so that fintech can encourage advancing state revenues.The existence of innovation in the field of technology, especially finance, has become a necessity for the realization of convenience for economic actors, especially SMEs actors to advance their business.

Conclusion and suggestion: Sharia fintech continues to strive to innovate so that it can be well received and reduce the obstacles that exist in society.
\end{abstract}

Keywords : Sharia Finthech, SMEs, Indonesia

\section{PENDAHULUAN}

Dewasa ini, pertumbuhan usaha yang memanfaatkan media dengan basis teknologi semakin meningkat dimana ditandai oleh munculnya banyak start up baru. Umat islam tidak boleh ketinggalan dalam segala hal termasuk bidang teknologi, apalagi yang berkaitan dengan ekonomi. Tren start up di Indonesia saat ini mengalami 
peningkatan yang sangat pesat. Startup lokal seperti Grab, Shopee, dan Traveloka, menjadi contoh dan memicu semangat munculnya startup-startup baru. Ada juga start up yang bergerak di bidang jasa keuangan, yang memberikan layanan keuangan kepada masyarakat. Selain itu, inovasi-inovasi baru bermunculan dibidang finansial dari lembaga keuangan yang sudah ada, keduanya dapat mendorong pertumbuhan perekonomian kearah yang lebih baik.

Secara perlahan perkembangan teknologi cukup pesat dan dapat merubah industri keuangan ke era digital. Saat ini yang sedang tren dan menjadi perbincangan masyarakat di Indonesia yaitu Financial Technology Syariah (Fintech Syariah). Fintech Syariah mulai diminati masyarakat karena sangat membantu serta sebagai media untuk pendanaan dan pembiayaan yang berbasis teknologi. Jadi masyarakat tidak perlu bersusah untuk antri melakukan pembayaran dan lain sebagainya karena bisa dilakukan dimana saja dan kapan saja lewat sebuah aplikasi.Penggunaan fintech syariah dipengaruhi oleh persepsi kemudahan penggunaan, persepsi manfaat dan inovasi dari konsumen. ${ }^{1}$ Sehingga, dengan munculnya Fintech Syariah ini diharapkan dapat meningkatkan kemaslahatan masyarakat agar lebih efektif dan efisien. Hal yang dapat dilakukan yaitu dengan cara mengembangkan Fintech Syariah tersebut untuk mempermudah layanan ekonomi bagi masyarakat. Sehingga dengan perlahan masyarakat bisa menggunakan fintech dengan baik. Tetapi apabila Fintech Syariah ini dikelola dengan efektif, maka akan sangat mempermudah segala aktivitas yang berkaitan dengan transaksi keuangan.

Akan tetapi yang menjadi tantangan, banyaknya SDM yang gaptek akan kemajuan teknologi. Keuangan syariah yang berbasis teknologi masih kalah dengan keuangan konvensional. ${ }^{2}$ Misalnya, Sumber Daya Manusia yang kurang pengetahuan dalam memanfaatkan teknologi masa kini, kurangnya promosi, strategi marketing yang masih kurang upgrade dan lain sebagainya. Negara dengan sistem keuangan konvensional lebih banyak penduduknya yang menggunakan fintech. Oleh karena itu, diperlukan adanya strategi, inovasi dan terobosan baru agar fintech syariah tersebut dapat terkelola dengan baik sehingga tidak menimbulkan dampak yang tidak diharapkan. Selain itu, Fintech Syariah memberikan banyak solusi yaitu sebagai bentuk media untuk membantu para pelaku usaha yang ingin berkembang. Sudah banyak perusahaan fintech yang mempromosikan gagasan inklusi keuangan, seperti membiayai sektor-sektor terbelakang seperti pertanian dan usaha mikro. ${ }^{3}$ Dengan banyaknya fitur-fitur layanan dari aplikasi Fintech Syariah yang sangat membantu tersebut akan berdampak positif pada perkembangan perekonomian di Indonesia. Dari paparan di atas dapat kita simpulkan

\footnotetext{
${ }^{1}$ Shaikh, dkk. Acceptance of Islamic Financial Technology (Fin Tech) Banking Services by Malaysian Users an Extension of Technology Acceptance Model, 2020, (Foresight 22 (3): hlm 367-83.

2 Hasnan Baber, "Financial Inclusion and Fintech: A comparative Study of Countries Following Islamic Financial and Conventional Finance: Qualitative Research in Financial Markets 12 (1), hlm 24-42.

${ }^{3}$ Hudaefi, dkk. "How does Islamic Fintech Promote the SDGs? Qualitative Evidence from Indonesia: Qualitative Research in Financial Markets 12 (4), hlm 353-66
} 
bahwa betapa pentingnya peran dari fintech syariah ini untuk kemajuan UMKM, sehingga perlu dilakukan penelitian terkait manfaat dan problematika penggunaannya.

\section{TINJAUAN PUSTAKA}

\section{Konsep Fintech Perspektif Konvesional dan Syariah}

Fintech adalah gabungan istilah financial dan technology atau teknologi finansial. Menurut The National Digital Research Centre (NDRC), di Dublin, Irlandia, mendefinisikan fintech sebagai "innovation in financial services" atau "inovasi dalam layanan keuangan fintech" yang merupakan suatu inovasi pada sector finansial yang mendapat sentuhan teknologi modern. Fintech sendiri didefinisikan sebagai aplikasi teknologi digital untuk masalah-masalah keuangan. Atau Fintech ini sebagai industri yang terdiri dari perusahaan-perusahaan yang menggunakan teknologi agar system keuangan dan penyampaian keuangan yang lebih efisien ${ }^{4}$ criteria fungsi, ada beberapa fungsi industry fintech secara umum, antara lain transaksi keuangan daring, uang elektronik, akun virtual, agregator, lembaga pinjaman, crowd funding, dan perencana keuangan personal. Fintech sendiri memiliki aktivitas-aktivitas dalam layanan jasa keuangan yaitu seperti pembayaran, transfer, kliring, dan penyelesaian. Akitivitas ini berkaitan erat dengan pembayaran mobile (baik oleh bank atau lembaga keuangan nonbank), dompet elektronik (digital wallet), dsb. Model - model ini bertujuan untuk meningkatkan inklusi keuangan dan memastikan akses konsumen yang lebih besar pada layanan jasa pembayaran serta memastikan berfungsinya system pembayaran dengan baik $^{5}$

Pada prinsipnya, fintech harus memiliki banyak layanan dan produk yang bisa dimanfaatkan oleh masyarakat luas, saat ini Bank Indonesia masih membagi 5 jenis fintech, yaitu yang pertamacrowdfunding, yaitu penggalangan dana, dimana prosesnya mengumpulkan sejumlah uang untuk suatu proyek atau usaha oleh sejumlah orang atau banyak orang, biasanya dilakukan melalui platform online. Yang kedua peer-to-peer lending, yaitu bentuknya berbasis utang berupa praktik pemberian pinjaman uang antar individu dimana peminjam dan pemberi pinjaman dipertemukan melalui platform yang diberikan oleh si perusahaan. Yang ketigamarket aggregator, di kategori ini, Fintech sebagai pembanding berbagai produk keuangan, dimana Fintech akan mengumpulkan data financial sebagai referensi oleh pengguna. Yang keempat Risk and Investment Management, merupakan perencana keuangan berbentuk digital yang akan membantu para pengguna untuk membuat rencana keuangan sesuai dengan kondisi keuangan yang ada. Yang kelima mobile payment / online banking, yaitu transaksi finansial yang meliputi

\footnotetext{
${ }^{4}$ Subagyo, Era Fintech: Peluang dan tantangan bagi Ekonomi Syariah, 2019, “El Jizya: Jurnal Ekonomi Islam, hlm 319-36

${ }^{5}$ Budi Wibowo, Analisa Regulasi Fintech dalam membangun Perekonomian, 2016, Jurnal Ekonomi dan Bisnis.
} 
pembayaran tagihan bulanan, transfer uang, pembayaran belanja pada pedagang di merchant digital, informasi saldo maupun mutasi rekening, dan masih banyak lagi. ${ }^{6}$ Definisi dari fintech syariah ialah perpaduan atau gabungan inovasi antara keuangan dan teknologi pada proses pelayanan keuangan dan investasi dengan berlandaskan nilai-nilai ajaran islam. Meskipun fintech syariah merupakan jenis inovasi baru namun perkembangannya cukup pesat. Pada dasarsanya dalam agama islam memiliki beberapa aturan yang menjadi acuan sesuai dengan prinsip islam.

\section{Peran Fintech}

Varian produk yang disediakan fintech untuk melayani keperluan keuangan masyarakat seperti crowd funding, mobile payment dan layanan transfer uang mewujudkan perubahan yang fundamental dalam dunia bisnis. Layanan keuangan crowdfunding dapat digunakan untuk mendapatkan dana dari berbagai Negara dengan mudah, walaupundari seseorang yang belum pernah ditemui sekalipun. Layanan fintech juga memudahkan pengiriman uang secara global ke seluruh dunia. Dalam fintech terdapat layanan pembayaran paypal yang dapat mengubah kurs uang secara otomatis, sehingga walaupun kita berada di luar negeri, kita masih dapat membeli barang dari Indonesia dengan sangat mudah. Fintech juga mempunyai peran yang cukup penting dalam memenuhi kebutuhan para konsumen, seperti; Pertama, Data dan informasi keuangan dapat diakses kapanpun dan dimanapun, Kedua Memberi harapan kepada para pebisnis kecil untuk dapat mengembangkan bisnisnya agar dapat menyamai bisnis besar sekalipun.

Perkembangan industry fintech sangat pesat di seluruh penjuru dunia. Hal ini dapat dibuktikan dengan munculnya berbagai startup bisnis di bidang fintech dan besarnya minat investasi di bidang fintech secara global. Terutama di Indonesia sendiri, bisnis dengan pengunaan fintech ini cukup menarik perhatian pebisnis yang ada di Indonesia. ${ }^{7}$

\section{Usaha Mikro Kecil dan Menengah (UMKM)}

Berdasarkan pada Undang -Undang Nomor 20 Tahun 2008, pengertian Usaha Mikro Kecil dan Menengah (UMKM) adalah 1. Usaha mikro adalah usaha produktif milik orang perorangan dan/atau badan usaha perorangan yang memenuhi kriteria usaha mikro sebagaimana diatur dalam undang-undang ini. 2. Usaha kecil adalah usaha ekonomi produktif yang berdiri sendiri, yang dilakukan oleh orang perorangan atau badan usaha yang bukan merupakan anak perusahaan atau bukan cabang perusahaan yang dimiliki, dikuasai, atau menjadi bagian baik langsung maupun tidak langsung dari

\footnotetext{
${ }^{6}$ Fadlan, Konsep Pembangunan Ekonomi Berbasis Islam, 2012, "Al Hikam: Jurnal Hukum dan Pranata Sosial 5 (2)

${ }^{7}$ Muzdalifa, dkk, Peran Fintech dalam Meningkatkan Keuangan Inklusif pada UMKM di Indonesia, "Jurnal Masharif Al Syariah Ekonomi dan Perbakan Syariah 3 (1)
} 
usaha menengah atau usaha besar yang memenuhi kriteria usaha kecil sebagaimana dimaksud dalam undang-undang ini. 3. Usaha menengah adalah usaha ekonomi produktif yang berdiri sendiri, yang dilakukan oleh orang perseorangan atau badan usaha yang bukan merupakan anak perusahaan atau cabang perusahaan yang dimiliki, dikuasai, atau menjadi bagian baik langsung maupun tidak langsung dengan usaha kecil atau usaha besar dengan jumlah kekayaan bersih atau hasil penjualan tahunan sebagaimana diatur dalam undang-undang ini. Usaha kecil dan menengah mempunyai peran yang strategis dalam pembangunan ekonomi nasional, dan penyerapan tenaga kerja selain itu berperan sebagai pendistribusian hasil-hasil usaha. ${ }^{8}$ UMKM merupakan sektor yang dapat menekan tingkat ketimpangan baik ekonomi dan sosial, menumbuhkan sistem kekeluargaan dan kerja sama serta dalam bidang ekonomi dapat meningkatkan daya beli terhadap konsumen di dalam negeri. ${ }^{9}$

Tabel 2.1 Kriteria UMKM

\begin{tabular}{|l|l|l|l|}
\hline No. & Usaha & Kriteria Aset & Kriteria Omzet \\
\hline 1 & Usaha Mikro & Maksimal 50 juta & Maksimal 300 juta \\
\hline 2 & Usaha Kecil & $>50$ juta -500 juta & $>300$ juta $-2,5 \mathrm{M}$ \\
\hline 3 & Usaha Menengah & $>500$ juta $-10 \mathrm{M}$ & $>2,5 \mathrm{M}-50 \mathrm{M}$ \\
\hline
\end{tabular}

Selain itu, menurut pasal 2 UU No. 20 tahun 2008, UMKM mempunyai asas yaitu, asas kekeluargaan, asas demokrasi ekonomi, asas kebersamaan, asas efisiensi berkeadilan, asas berkelanjutan,asas berwawasan lingkungan, asas kemandirian, asas keseimbangan, asas kemajuan dan asas kesatuan ekonomi nasional. Berdasarkan pengertian dan kriteria UMKM diatas, tujuan UMKM di Indonesia adalah menumbuhkan dan mengembangkan usahanya dalam rangka membangun perekonomian nasional berdasarkan demokrasi ekonomi yang berkeadilan. Selain menggunakan nilai moneter sebagai kriteria, Departemen Perindustrian dan Badan Pusat Statistik (BPS) selama ini menggunakan jumlah pekerja sebagai ukuran untuk mendefinisikan kriteria skala usaha. Menurut BPS, Usaha Mikro Indonesia (UMI) adalah unit usaha dengan jumlah pekerja tetap hingga 4 orang; Usaha Kecil (UK) antara 5 hingga 19 pekerja; Usaha Menengah (UM) dari 20 hingga 99 orang. Perusahaan-perusahaan dengan jumlah pekerja di atas 99 orang masuk dalam kategori Usaha Besar (UB). Jadi dalam menentukan skala usaha tergantung dari sisi mana dinilainya, apakah dari sisi moneter atau dari segi jumlah tenaga kerja yang diserap. Keduanya akan berbanding lurus, jika modal yang dikeluarkan besar, kecenderungan produksi usaha tersebut juga besar, maka jumlah tenaga kerja yang

\footnotetext{
${ }^{8}$ Acmad Basori Alwi, Pembiayaan berbasis Teknologi Informasi (Fintech) yang berdasarkan Syariah, 2018, "Jurnal Pemikiran dan Pembaharuan Hukum Islam 21 (2).

${ }^{9}$ Wulansari, dkk, Akselerasi Pertumbuhan Ekonomi melalui Sinergi UMKM dan Good Governance di Indonesia, 2017, "Prosidin seminar Nasional dan Call for Paper Ekonomi dan Bisnis.
} 
berhasil dihimpun tentu juga besar, begitu juga sebaliknya.

UMKM sangat berpengaruh bagi kestabilan ekonomi dan menambah devisa negara termasuk Indonesia. Adanya UMKM membantu kita bisa mengentaskan masyarakat dari jurang kemiskinan dan meratakan tingkat perekonomian rakyat kecil. Masyarakat lebih produktif dan inovatif bahkan bisa berdiri sendiri apabila di tempat ia bekerja sebelumnya mengalami kebangkrutan sehingga ia tidak lagi bergantung pada orang lain dan ekonomi di Indonesia pun lebih merata dan masyarakat memiliki penghasilan berkecukupan. Selain itu, disini kita juga bisa menjadi bos dari UMKM kita sendiri serta tidak terikat waktu kapan dan dimana kita bekerja seperti saat bekerja di kantor yang harus tepat waktu. Kita juga bisa mengenalkan produk kita yang asli dari budaya Indonesia kepada mancanegara. Saat ini pula sudah banyak diterapkan pelatihan kerja UMKM bagi pelaku usaha, apalagi canggihnya teknologi yang mendukung promosi produk UMKM semakin maju dan mandiri.

\section{METODE PENELITIAN}

Paper ini merupakan studi pustaka dengan menggunakan berbagai sumber. Sifat dalam penelitian ini ialah deskriptif kualitatif yang menjelaskan objek tertentu. Penelitian ini fokus pada problematika dan peran yang ditemukan pada fintech terhadap perkembangan UMKM di Indonesia. Penelitian ini memiliki sifat deskriptif yang memiliki tujuan untuk menjelaskan dan memaparkan hasil penelusuran mengenai bagaimana manfaat yang dirasakan oleh UMKM dan problematika apa saja yang dihadapi UMKM dengan adanya pemanfaatan Fintech syariah yang sesuai dengan ajaran syariat.

Paper ini menggunakan data sekunder, data sekunder ialah jenis data yang diambil seorang peneliti untuk mendukung sebuah penelitian secara ilmiah dengan melakukan rangkaian studi pustaka melalui beberapa media seperti jurnal, majalah, internet, karya ilmiah, artikel dan sumber lain yang diperlukan. Pengumpulan data yang dibutuhkan pada penelitian ini menggunakan teknik dengan beberapa metode studi pustaka, metode ini digunakan dengan cara menemukan berbagai dasar-dasar teori yang berhubungan dengan cara kerja dan konsep pada fintech yang perkembangannya sangat pesat di Era modern saat ini agar tidak menyimpang dari berbagai prinsip yang terdapat dalam ajaran agama islam dan juga dapat mengetauhi bagaimana manfaat dan kendala yang terdapat pada perkembangan fintech dalam membantu meningkatkan UMKM di Indonesia.

\section{HASIL DAN PEMBAHASAN}

\section{Langkah-langkah Fintech Syariah Dalam Meningkatkan UMKM.}

Fintech merupakan inovasi baru yang membuktikan majunya zaman dengan cepat dan sangat berdampak pada sektor ekonomi. Fintech merupakan salah satu bentuk bisnis yang menggunakan perangkat lunak dan teknologi canggih yang berfokus pada bidang 
layanan keuangan. Tujuan adanya fintech sejalan dengan tujuan transaksinya yang ingin menjaga dan memelihara kebaikan bersama, serta meminimalisir adanya keburukan baik di dunia maupun akhirat. Melihat dari besarnya potensi perkembangan pasar muslim di seluruh dunia, kesempatan ini digunakan oleh para startup fintech untuk membangun inovasi fintech syariah. Kriteria yang harus dimiliki oleh fintech syariah agar sesuai dengan syariat islam yaitu pada transaksinya tidak mengandung unsur riba, tidak dilakukan dengan cara penipuan (gharar), tidak memberikan mudharat pada penggunanya, dan harus ada kejelasan antara pembeli dan penjual. Fintech syariah pertama diawali oleh perusahaan startup beehive di dubai pada tahun 2004. Pembiayaan yang disediakan oleh fintech syariah yang mendapat sertifikat syariah pertama ini menggunakan system peer to peer landing market place yang murah kepada para UMKM. Pada tahun 2016 di wilayah asia tenggara tepatnya di Singapura, memperkenalkan produk fintech syariah capital boost yang sudah memperoleh sertifikat kepatuhan syariah dari financial shariah advisory consultasy Singapura, adapun pada tahun 2014 terdapat fintech syariah dari singapura yang berhasil menguasai pangsa pasar di Indonesia dengan system crowdfunding dan sudah mempunyai layanan keuangan syariah. Crowdfunding syariah terus mengalami perkembangan di seluruh belahan dunia dalam waktu beberapa tahun terakhir.

Fintech syariah sendiri yang saat ini sudah berdiri di Indonesia diantaranya adalah indves, syarQ, start zakat, paytren, dan lain-lain. Fintech syariah yang memiliki sertifikasi halal dari MUI pertama di Indonesia ialah Paytren pada tahun 2017.Hingga saat ini financial teknologi (fintech) di Indonesia masih didominasi oleh fintech konvensional. ${ }^{10}$ Dalam situs resmi OJK hingga pada juni 2019 pada data yang telah dipaparkan sejumlah 113 perusahaan penyelenggara layanan keuangan telah mendapat ijin resmi 0JK, seiring perkembangannya para layanan fintech tersebut secara bertahap masuk kedalam system keuangan syariah. Hal ini terbukti dengan adanya para startup bisnis usaha yang mulai menjalankan bisnisnya dengan mengikuti prinsip-prinsip syariah dan sudah terdaftar pada OJK dan DSN-MUI, mulai dengan cara melihat produk yang akan ditawarkan, kejelasan akad yang digunakan, dan juga aturan-aturan didalamnya yang sesuai dengan ajaran islam. Dengan memperhatikan berbagai macam aspek dan perkembangan teknologi yang begitu pesat di Indonesia, pihak Majelis Ulama Indonesia (MUI) mnegeluarkan pendapat tentang pertanyaan masyarakat terkait dengan adanya penawaran produk berbasis syariah dari para startup bisnis syariah. Hal ini dilakukan untuk memberi penjelasan tentang berbagai aturan dan ketentuan layanan keuangan berbasis teknologi yang berdasarkan pada syariah islam.

MUI mengeluarkan Fatwa Dewan Syariah Nasional-Majelis Ulama Indonesia (DSN-

\footnotetext{
${ }^{10}$ Hasnan Baber, "Financial Inclusion and Fintech: A comparative Study of Countries Following Islamic Financial and Conventional Finance: Qualitative Research in Financial Markets 12 (1), hlm 24-42.
} 
MUI)No.117/DSN-MUI/II/2018 Tentang Layanan

Pembiayaanberbasisteknologiinformasiberdasarkanprinsipsyariahyang terdiri atas delapan bagian : 1) ketentuan umum; 2) ketentuan hukum; 3) subjek hukum; 4) ketentuan terkait pedoman umum layanan pembiayaan berbasis teknologi informasi; 5) mode layanan pembiayaan berbasis teknologi informasi; 6) ketentuan terkait mekanisme dan akad; 7) penyelesaian perselisihan; 8) penutup. Fatwa tersebut dikeluarkan dengan tujuan agar para masyarakat dapat memahami ketentuan dan aturan hukum yang dijadikan sebagai landasan kesyariahan dari berbagai produk yang dikeluarkan oleh para pebisnis startup diIndonesia. ${ }^{11}$

Terdapat beberapa prosedur yang digunakan pada pembiayaan atau pinjam meminjam yang sesuai dengan akad syariah, prosedur tersebut diantaranya yaitu; 1 . Pada website yang tersedia peminjam melakukan pengajuan peminjaman; 2. Berkas identitas peminjam dikirim melalui website; 3 . Mengirim dokumen yang dibutuhkan sesuai dengan kebutuhan pembiayaan; 4. Tujuan dikirimkannya dokumen tersebut untuk mendukung tujuan para penyelenggara layanan dalam membantu pendanaan para pengusaha bisnis UMKM. Namun untuk para usaha perorangan dan tidak mempunyai dokumen usaha yang diberikan maka biasanya hanya berbentuk slip gaji atau fotokopi rekening tabungan;5. ilakukan analisa terkait kelayakan pemberian pinjaman oleh penyelenggara layanan kepada para peminjam dari segi jangka waktu dan kemampuan yang dimiliki peminjam dalam pengembalian. 6. Setelah mengeluarkan hasil analisa dan masuk kategori layak diberikan pinjaman, penyelenggara memberi informasi kepada pemberi pinjaman bahwa terdapat pihak yang mengajukan pinjaman yang layak diberikan pinjaman serta siap melakukan akad pinjam meminjam; 7. Akad pembiyaan dilakukan antara penerima pinjaman dan pemberi pinjaman dengan skema al qardh. Pemberi pinjaman memberikan pinjaman atas tagihan yang diberikan, dilanjutkan dengan akad wakalah bil ujrah, pemberi pinjaman mewakilkan pada penyelenggara layanan untuk membantu melakukan pengurusan atas tagihan yang diberikan peminjam. Akad al-qardh maupun wakalahbilujrahdilakukansecaraonlinemelaluiwebsite penyelenggara layanan. Dapat pula menggunakan akad musyarakah untuk segementasi tertentu; 8. Penerima pinjaman memberikan jaminan berupa tagihan serta giro sesuai tanggal jatuh tempo pinjaman. Untuk pinjaman perorangan pemberi pinjaman dapat meminta jaminan lain sesuai kesepakatan para pihak; 9. Pinjaman dicairkan melalui rekening virtual penerima pinjaman pada bank yang sudah ditunjuk dan bekerja sama dengan penyelenggara layanan. ${ }^{12}$

\footnotetext{
${ }^{11}$ Nasution, dkk, Urgensi Fintech dalam Kurikulum Pendidikan Tinggi, "Iqtishoduna: Jurnal Ekonomi Syariah" 8 (2)

${ }^{12}$ Acmad Basori Alwi, Pembiayaan Berbasis Teknologi Informasi (Fintech) yang berdasarkan Syariah, 2018, "Al Qonun: Jurnal Pemikiran dan Pembaharuan Hukum Islam 21 (2)
} 


\section{Kendala fintech syariah dalam meningkatkan UMKM}

Kemajuan teknologi saat ini sudah sangat canggih termasuk bidang keuangan. Banyak masyarakat yang menggunakan manfaatnya untuk membuka usaha onlin,order online dan transaksi online. Misalnya m-banking, belanja pakaian, belanja kebutuhan, dan lainlain bisa lewat aplikasi online dan hanya dengan menggunakan handphone saja kita sudah mendapatkan apa yang kita inginkan. Kecanggihan tersebut sangat mempermudah kita melakukan transaksi dan belanja serta menguntungkan bagi pelaku usaha untuk mempromosikan produknya, sehingga dapat menghemat waktu, tenaga dan modal karena tidak perlu lagi mempunyai tempat atau toko untuk membuka usaha kita.

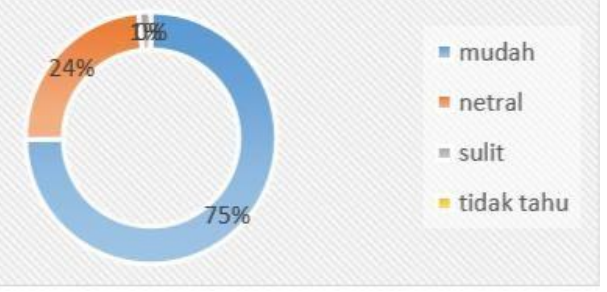

Gambar 1. Kemudahan Layanan keuangan untuk UMKM

Sumber;(Winarto 2020)

Dari gambar di atas dapat diambil kesimpulan bahwa secara umum fintech memudahkan bagi palaku UMKM.

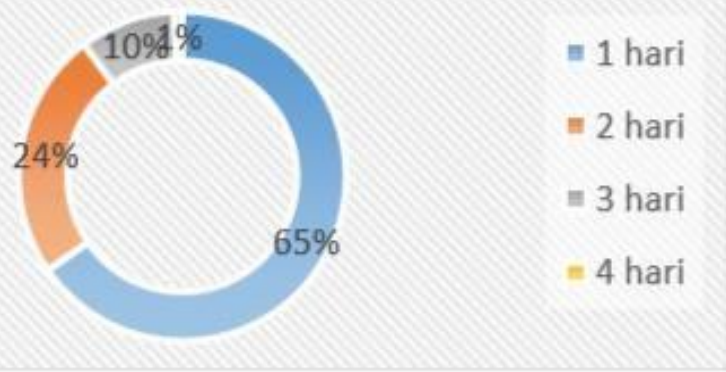

Gambar 2. Akses pembiayaan lebih mudah dan cepat

Sumber; (Winarto 2020)

Dari gambar ini memberikan penegasan bahwa fintech yang ada memilki pelayanan yang cepat.

Namun, di sisi lain, fintech masih menemukan banyak tantangan yang dapat menghambat kemajuan teknologi tersebut. tantangan itu pada akhirnya akan menyebabkan tehambatnya percepatan kemajuan bangsa jika tidak segera diatasi. Hal ini karena masyarakat indonesia masih didalamculture lag, masyarakat masih ketinggalan oleh zaman dan tidak mau merubah bahkan tidak mau menerima budaya baru yang dianggapnya sebagai budaya asing yang mengancam budaya bangsa. Karena menurut masyarakat tersebut, teknologi malah membuat kecanduan dan hilangnya fungsi sosial. Hal tersebut yang menyebabkan tidak adanya interaksi sosial lagi antara manusia satu 
dengan manusia lainnya, ini sedikit berbeda dengan temuan penggunaan fintech syariah dipengaruhi oleh persepsi kemudahan penggunaan, persepsi manfaat. dan inovasi dari konsumen. Misalnya, kalau saja pasar dan toko-toko mulai berkurang maka yang terjadi adalah manusia tidak dapat bersosialisasi lagi padahal manusia diciptakan sebagai makhluk sosial. Jadi, masyarakat tersebut takut menerima teknologi baru yang bisa menggantikan budaya kita yangsebenarnya. Hal ini memang menjadi tantangan bagi budaya masyarakat kita yang memiliki budaya sosial tinggi.

Kendala fintech syariah yang lainnya yaitu, fintech konvensional yang terdaftar lebih mudah dan lebih bervariasi sedangkan fintech syariah masih kekurangan modal sehingga kurangnya sumber daya, inovasi produk dan marketing ${ }^{13}$, ini tentu menjadi hambatan yang perlu diupayakan solusinya oleh semua pihak terutama pemerintah sebagai pembuat regulasi. Tetapi saatini, Asosiasi Fintech Syariah Indonesia akan ditunjuk oleh Otoritas Jasa Keuangan (OJK) menjadi Self Regulatory Organization (SRO) yang akan membantu regulator mengembangkan sekaligus mengawasi operasional Fintech Syariah. Selain itu, regulator dan industri bersama pengembangan ekosistem yang dapat menunjang literasi dan partisipasi di fintech syariah. Sinergi atau kolaborasi antar fintech syariah juga bisa menjadisolusi.

Komite Nasional Keuangan Syariah(KNKS)bersamastakeholder lain saat ini sedang menyiapkan Rancangan Undang-Undang Ekonomi Syariah yang akan memasukkan peraturan fintech syariah ${ }^{14}$ jika ini sudah dikeluarkan juga akan menjadi salah satu daya tarik bagi investor. Selain itu, pemerintah disini sebenarnya sangat berperan penting bagi fintech syariah, pemerintah juga harusnya lebih kuat mendukung infrastruktur yang ada apalagi Presiden sudah mencanangkan Indonesia sebagai pusat ekonomi syariah dunia. Instrumen Pemerintah seperti BUMN, BUMD, Kementerian perlu didorong agar berpartisipasi aktif menyuburkan industri seperti UMKM. Seperti dengan menggunakan alat pembayaran syariah, menggunakan jasa fintech syariah untuk menunjang program kerja, sebagai modal kerja, memenuhi kebutuhan pegawai dan lainnya agar industri seperti UMKM bisa meningkat dan perekonomian di Indonesia merata.

Sebagai salah satu negara dengan penduduk muslim terbesar di dunia, layanan keuangan digital atau financial technology (fintech) syariah memiliki potensi yang besar untuk semakin bertumbuh. Asosiasi Fintech Syariah Indonesia (AFSI) yang baru berusia satu tahun, saat ini mencatat anggota yang teregistrasi baru mencapai 55 anggota. Ketua Umum Asosiasi Fintech Syariah Indonesia, Ronald Wijaya menyampaikan, dari 55 fintech syariah tersebut, 12 anggotanya merupakan penyedia layanan Peer-to-Peer Lending (P2P) yang diatur dalam Peraturan Otoritas Jasa Keuangan (POJK)

\footnotetext{
${ }^{13}$ Hasnan Baber, "Financial Inclusion and Fintech: A comparative Study of Countries Following Islamic Financial and Conventional Finance: Qualitative Research in Financial Markets 12 (1), hlm 24-42.

${ }^{14}$ Kharisma, dkk, Urgency of Financial Technology (Fintech) Laws in Indonesia, "International Journal of Law and Management 63 (3), hlm 320-31
} 
77/P0JK.01/2016, sementara sisanya masuk dalam POJK Inovasi Keuangan Digital. Namun, Secara keseluruhan, fintech syariah sebetulnya memiliki 100 anggota. Tetapi yang sudah menjalankan kewajiban seperti membayar iuran anggota, melengkapi akadnya, secara resmi ada 55anggota. ${ }^{15}$

Selain itu, kendala fintech syariah yaitu harus mempunyai DPS atau Dewan Pengawas Syariah, sedangkan disisi lain hal tersebut sangat memberatkan karena biayanya cukup besar sedangkan fintech syariah kebanyakan dari perusahaan startup (pemula) dengan modal yang masih terbatas. Persoalan ini juga harus bisa difasilitasioleh pemerintah untukmendorong perkembangan fintech syariah di Indonesia. Solusinya adalah dengan cara memberikanalternatif seperti satu DPS bisa menjadi pengawas di beberapa fintech syariah, sehingga meskpun belum terdaftar mempunyai infrastruktur yang sesuai dengan regulasi OJK. ${ }^{16}$

Kendala lainnya adalah terkait proses pendaftaran perizinan ke Otoritas Jasa Keuangan yaitu yang memakan waktu cukup lama dibandingkan pengajuan perizinan fintech konvensioal. ${ }^{17}$ Ditambah lagi dengan pengetahuan masyarakat mengenai fintech yangmasih terbatas, apalagi terkait fintech syariah. ${ }^{18}$ Namun, hal tersebut harus menjadi semangat untuk terus berkembang karena potensi pertumbuhan fintech syariah sangat besar sebab Indonesia merupakan negara dengan penduduk muslim terbanyak. Kita juga merupakan digital ready country dengan jumlah pengguna internet yang sangatbesar.

Kendala fintech syariah tersebut adalah yang menyebabkan terhambatnya peningkatan UMKM di Indonesia untuk semakin berkembang, tadi sudah dijelaskan bahwa seharusnya pemerintah disini sangat berperan penting bagi jalannya semua sistem yang ada di Indonesia agar pengajuan apapun bisa diselesaikan dengan cepat. ${ }^{19}$ Selain itu, masalah dari masyarakat itu sendiri yang harus mau menerima budaya baru yaitu canggihnya fintech syariah tersebut sebagai media pengembangan UMKM yang ada di Indonesia. Agar UMKM berjalan lancar, perekonomian stabil yang pada akhirnya terwujudlah masyarakat yang mampu mencapai maslahah.

\section{Peranan Fintech Syariah untuk Peningkatan UMKM}

\footnotetext{
${ }^{15}$ Setiani, dkk, Fintech Syariah: Manfaat dan Problematika Penerapan pada UMKM, 2020, "Jurnal Masharif Al Syariah Jurnal Ekonomi dan pErbankan Syariah 5 (1), hlm 75-90

${ }^{16}$ Hiyanti, dkk, Peluang dan tantangan Fintech Syariah di Indonesia, 2019, Jurnal IImiah Ekonomi Islam, hlm 32633

17 Mahendra Galih Prasaja, Tantangan dan Masa Depan Financial Technology Terhadap Perkembanga Industri Keuangan Syariah di era Revolusi Industri 4.0, 2020, Jurnal SEGMEN Manajemen dan Bisnis 16 (2)

${ }^{18}$ Hiyanti, dkk, Peluang dan tantangan Fintech Syariah di Indonesia, 2019, Jurnal Ilmiah Ekonomi Islam, hlm 32633

${ }^{19}$ Kharisma, dkk, Urgency of Financial Technology (Fintech) Laws in Indonesia, “International Journal of Law and Management 63 (3), hlm 320-31
} 
Fintech berkembang pesat dalam memperbaiki dan memajukan perekonomian dunia di Era globalisasi ini, salah satunya pada lembaga keuangan syariah khususnya pada perbankan syariah. Jumlah penduduk yang besar ini harus diimbangi dengan banyaknya lapangan kerja yang tersedia. Indonesia harus mampu mengatasi hal tersebut dengan mendukung dan menfasilitasi usaha-usaha yang didirikan oleh anaknegeri.

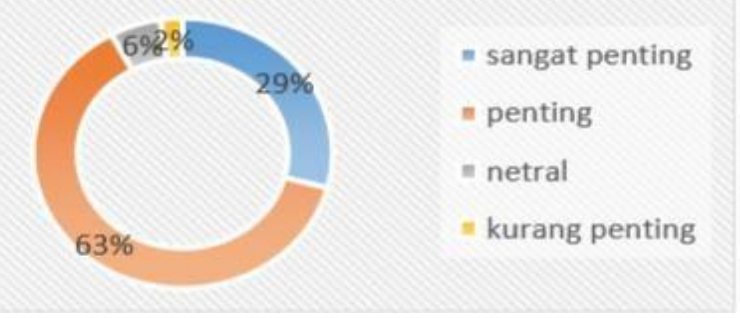

Gambar 3. Kontribusi Fintech bagi pemberdayaan UMKM

Sumber;(Winarto 2020)

Dari gambar di atas menegaskan bahwa fintech berperan penting bagi kemajuan UMKM. Maka dari itu, kehadiran sejumlah perusahaan fintech turut berkontribusi dalam pengembangan UMKM. Tidak hanya sebatas membantu pembiayaan modal usaha, peran Fintech juga sudah merambah keberbagai aspek seperti layanan pembayaran digital dan pengaturan keuangan. Pertama Pinjaman Modal, perusahaan Fintech memberikan layanan pinjaman modal dengan proses pengajuan yang lebih sederhana dibandingkan lembaga keuangan konvensional seperti bank tanpa perlu menyerahkan jaminan dan cukup melengkapi beberapa persyaratan dokumen saja, pinjaman yang diajukan dapat cair dalam waktu relative singkat yakni kurang dari seminggu. Dengan itu, layanan pinjaman online ini menjadi alternative dari pinjaman konvensional bank atau perusahaan pinjamanlainnya. Kedua Layanan Pembayaran Digital, perusahaan fintech juga menyediakan pembayaran digital yang lebih mudah dan aman bagi pebisnis. Dengan proses pembayaran yang mudah dan aman, maka akan mampu menarik lebih banyak konsumen sehingga memberikan keuntungan bagi pelaku bisnis. Salah satu Fintech yang menyediakan pembayaran digital adalah apolikasi Jenius yang beroperasi dengan perusahaan jasa transportasi online. Ketiga Layanan Pengaturan Keuangan, Ada sejumlah aplikasi yang menawarkan layanan pengaturan keuangan. Inovasi ini bertujuan membantu pebisnis UMKM dalam mengatur keuangan perusahaan. Layanan yang diberikan seperti pencatatan pengeluaran, pemantauan kinerja investasi, dan konsultasi keuangan tanpa dikenakan biaya.

Ketika sumber daya produktif dapat dimanfaatkan secara optimal dan dialokasikan secara merata, maka itu membuat pertumbuhan ekonomi dapat tercapai.Tujuan pembangunan ekonomi sendiri yaitu untuk mencapai sasaran utama dalam menciptakan kesejahteraan dan mengurangi ketimpangan. Dalam proses pembangunan perekonomian Indonesia, sektor UMKM memiliki peranan yang sangat strategis dan penting. Usaha kecil dan menengah (UKM) mempunyai peran yang strategis 
dalam membangun perekonomian suatu Negara ataupun daerah, tidak terkecuali di Indonesia.

Usaha mikro kecil menengah menjadi salah satu prioritas dalam agenda pembangunan di Indonesia, hal ini terbukti dari bertahannya sektor UKM saat terjadi krisis hebat tahun 1998, bila dibandingkan dengan sektor lain yang lebih besar justru tidak mampu bertahan dengan adanya krisis. Usaha mikro kecil menengah atau UMKM memiliki peran penting dalam perekonomian masyarakat Indonesia. Perintah memandang penting keberadaan para pelaku UMKM bersama dengan Koperasi memiliki wadah secara khusus dibawah kementrian koperasi dan UKM. Dengan peran yang sangat penting yang dimiliki UMKM, maka Fintech akan dapat lebih membantu dalam menangani masalah pendanaan agar UMKM dapat berkembang lebih maju dan dapat menyongsong Indonesia sebagai salah satu Negara Ekonomi Digital terbesar tahun2024.20

\section{KESIMPULAN}

Penulis menyimpulkan bahwa perkembangan financial berbasis syariah sudah mulai berkembang di masyarakat. fintech syariah adalah inovasi pelayanan terbaru bidang keuangan yang berbasis teknologi dengan tidak melupakan syariat islam sehingga memberi manfaat serta membantu masyarakat agar dengan mudah mengakses produk dan layanan keuangan yang tidak terdapat pada layanan keuangan di masa lalu. Meskipun terdapat beberapa kendala dalam peningkatannya di Indonesia seperti kurangnya pengetahuan masyarakat tentang teknologi dikarenakan karakter masyarakatnya yang masih bersifat tradisional ataupun dapat menimbulkan kesenjangan sosial dimana dapat berpengaruh pada tingginya tingkat individualisme pada masyarakat. Minimnya modal yang dimiliki fintech syariah.Namun fintech syariah tetap berusaha untuk melakukan inovasi agar dapat diterima dengan baik dan mengurangi kendala yang ada pada masyarakat.

\section{DAFTAR PUSTAKA}

Alwi, Achmad Basori. 2018. "Pembiayaan Berbasis Teknologi Informasi (Fintech) Yang Berdasarkan Syariah." Al-Qanun: Jurnal Pemikiran Dan Pembaharuan Hukum Islam 21 (2). https://doi.org/10.15642/alqanun.2018.21.2.255-271.

Baber, Hasnan. 2020. "Financial Inclusion and FinTech: A Comparative Study of Countries Following Islamic Finance and Conventional Finance." Qualitative Research in Financial Markets 12 (1): 24-42. https://doi.org/10.1108/QRFM-12-2018-0131.

\footnotetext{
${ }^{20}$ Wulansari, dkk, Akselerasi Pertumbuhan Ekonomi melalui Sinergi UMKM dan Good Governance di Indonesia, 2017. "Prosiding Seminar Nasional dan Call for Paper Ekonomi dan Bisnis".
} 
Fadlan, Fadlan. 2012. "KONSEP PEMBANGUNAN EKONOMI BERBASIS ISLAM (Sebuah Upaya Pembangunan Ekonomi Indonesia Yang Adil, Makmur, Dan Sejahtera)." $A L$ IHKAM: Jurnal Hukum \& Pranata Sosial 5 (2). https://doi.org/10.19105/allhkam.v5i2.293.

Hiyanti, Hida, Lucky Nugroho, Citra Sukmadilaga, Tettet Fitrijanti, Universitas Mercu Buana, and Fintech Syariah. 2019. "Jurnal Ilmiah Ekonomi Islam , 5 ( 03 ), 2019 , 326-333 Peluang Dan Tantangan Fintech ( Financial Technology ) Syariah Di Indonesia” 5 (03): 326-33.

Hudaefi, Fahmi Ali. 2020. "How Does Islamic Fintech Promote the SDGs? Qualitative Evidence from Indonesia." Qualitative Research in Financial Markets 12 (4): 353-66. https://doi.org/10.1108/QRFM-05-2019-0058.

Kharisma, Dona Budi. 2021. "Urgency of Financial Technology (Fintech) Laws in Indonesia." International Journal of Law and Management 63 (3): 320-31. https://doi.org/10.1108/IJLMA-08-2020-0233.

Muzdalifa, Irma, Inayah Aulia Rahma, and Bella Gita Novalia. 2018. "Peran Fintech Dalam Meningkatkan Keuangan Inklusif Pada UMKM Di Indonesia (Pendekatan Keuangan Syariah)." Jurnal Masharif Al-Syariah: Jurnal Ekonomi Dan Perbankan Syariah 3 (1). https://doi.org/10.30651/jms.v3i1.1618.

Nasution, Dewi Sartika. 2017. "Urgensi Fintech Dalam Kurikulum Pendidikan Tinggi." IqtIshaduNa - Jurnal Ekonomi Syariah 8 (2).

Prasaja, Mahendra Galih. 2020. “Tantangan Dan Masa Depan Finansial Technology Terhadap Perkembangan Industri Keuangan Syariah Di Era Revolusi Industri 4.0." SEGMEN: Manajemen Dan Bisnis 16 (2).

Setiani, Dina Dwi, Hanien Nivanty, Wardah Lutfiah, and Lilik Rahmawati. 2020. "Fintech Syariah: Manfaat Dan Problematika Penerapan Pada UMKM." Jurnal Masharif AlSyariah: Jurnal Ekonomi Dan Perbankan Syariah 5 (1): 75-90.

Shaikh, Imran Mehboob, Muhammad Asif Qureshi, Kamaruzaman Noordin, Junaid Mehboob Shaikh, Arman Khan, and Muhammad Saeed Shahbaz. 2020. "Acceptance of Islamic Financial Technology (FinTech) Banking Services by Malaysian Users: An Extension of Technology Acceptance Model.” Foresight 22 (3): 367-83. https://doi.org/10.1108/FS12-2019-0105.

Subagiyo, R. 2019. "Era Fintech: Peluang Dan Tantangan Bagi Ekonomi Syariah.” El-Jizya: $\begin{array}{lllll}\text { Jurnal Ekonomi } & \text { Islam } & 7 & \text { (2): }\end{array}$ http://ejournal.iainpurwokerto.ac.id/index.php/eljizya/article/view/3457.

Wibowo, Budi. 2016. “Analisa Regulasi Fintech Dalam Membangun Perekonomian Di Indonesia." Jurnal Eknonomi Dan Bisnis. 
Winarto, Wahid Wachyu Adi. 2020. "Peran Fintech Dalam Usaha Mikro Kecil Dan Menengah (UMKM)." Jesya (Jurnal Ekonomi \& Ekonomi Syariah) 3 (1): 61-73. https://doi.org/10.36778/jesya.v3i1.132.

Wulansari, Nofita, Wahyu, and Yunus Kurniawan. 2017. "Akselerasi Pertumbuhan Ekonomi Melalui Sinergi UMKM Dan Good Governance Di Indonesia." Prosiding Seminar Nasional Dan Call For Paper Ekonomi Dan Bisnis 2017. 